\title{
PARTICIPATION OF CHILDREN IN DECISION-MAKING AND THEIR PSYCHOSOCIAL WELLBEING WITHIN THE CHILD PROTECTION SYSTEM IN ST.PETERSBURG, RUSSIA
}

The child's right to be heard is a cornerstone of the Convention on the Rights of the Child. Children growing up outside of their natural families particularly often find themselves in situations where this right should be fulfilled. In Russia, the child's participation in decision-making at the time of their separation from their parents, and during their stay in the children's homes, is often overlooked by both static monitoring and academic studies. In our study we raise the following research questions: To what extent is the right of a child separated from his or her natural parents to participate in decisionmaking respected? How does involvement in decision-making impact their psychosocial wellbeing? The study covered 215 children aged between ten and seventeen (mean age fourteen years) living in children's homes in St. Petersburg. Our findings show that $42 \%$ of children believe that they were not heard when the decisions affecting their interests were made. Talking with a social counsellor and having a trusted adult in the children's home add to children's perceptions that they have been heard. Limited participation in decision-making increases the odds of psychosocial difficulties in the binary logistic regression. We conclude that limited participation in decisionmaking negatively impacts the effectiveness of work with children and their psychosocial well-being. Since the degree and effectiveness of children's participation depends primarily on the attitudes of professionals and their ability to create trusting relationships with children, a further increase in children's participation will require a change in the professional paradigm of specialists. Specific methods for increasing the participation of children should be introduced in the daily practice of child welfare workers.

Veronika Odinokova- PhD, senior researcher, Sociological Institute of FCTAS RAS, St. Petersburg, Russian Federation. Email: veronika.odinokova@gmail.com

Maia Rusakova-PhD, senior researcher, Sociological Institute of FCTAS RAS, St. Petersburg, Russian Federation. Email: maia@ngostellit.ru 
Key words: sociology of childhood, children, decision-making, wellbeing, child protection, children's rights

DOI: 10.17323/727-0634-2019-17-4-643-656

The child's right to be heard is a cornerstone of the Convention on the Rights of the Child (UN 1989) ratified by the Soviet Union in 1990. Under this Convention, the state guarantees to every child capable of forming his or her own views the right to express those views freely in all matters affecting the child; the views of the child are to be given due weight in accordance with the age and maturity of the child (Article 12). For this purpose, a child has the right to speak before a court or in an administrative proceeding affecting their interests. With the evolution of this right, the term 'child's participation in making decisions that affect their interests' emerged. The Committee on the Rights of the Child defines children's participation as 'ongoing processes which include information-sharing and dialogue between children and adults based on mutual respect, and in which children can learn how their views and those of adults are taken into account and shape the outcome of such processes' (UN Committee 2009:5).

Growth of the sociology of childhood became an important driver in understanding the significance of children's participation. The sociology of childhood developed quite rapidly as a critical discipline within the field of childhood studies. Two key volumes that attempted to establish a new conceptual and empirical field for the sociology of childhood were published in the early 1990s by Allison James and Alan Prout (1997) and Jens Qvortrup (et al.) (1994). The sociology of childhood relies on the ideas and methodology of post-structural and critical discourse and feminist theory, seeking to strengthen the involvement of children and adolescents in all aspects of sociology and the life of the society. Representing children as social actors is considered one of the most important theoretical developments in the sociology of childhood, because doing so deems children's lives worthy of inquiry, recognizing children for their value in the development of social theory (James 2009). This approach requires a wider involvement of children in developing theory, policies and research, including matters of upbringing outside the natural family, child protection, healthcare and education.

The cornerstone to this emerging approach to childhood is that children and adolescents proactively create their own childhood, thus driving changes in the entire social environment. This contradicts the existing predominant perception of childhood, with children and adolescents perceived as passive recipients of care, being themselves immature and dependent (Corsaro 1997). The sociology of childhood claims to take the perspective of children and adolescents seriously. Researchers and field specialists seek to find out, evaluate and make use of the views of children and adolescents, who are deemed to be experts in matters of their own lives. 
Children separated from their families and living in public care very often find themselves in situations where their opinions should be taken into consideration. The child's involvement in decision-making can take place in a variety of contexts, including the choice of daily activities, social and psychological support arrangements, decisions with regard to the child's future, e.g. where and with whom he or she would live (Ten Brummelaar et al. 2018). Child participation increasingly attracts the attention of researchers outside Russia. Their work confirms that the possibilities for children growing up outside their natural families to take part in decision-making processes are limited (Van Bijleveld et al. 2015; Cossar et al. 2016). At the same time, we know little about the opportunities for participation in decision-making among children in the context of the child protection systems in Russia. This has become the main problem that inspired our study.

\section{The decision-making processes of young people in Russian residential care homes}

Children's participation in decision-making is commonly declared as a child's right with positive implications both for the society and the child. Given this common perception, empirical studies of the consequences of children's empowerment or disempowerment are surprisingly rare (Ten Brummelaar et al. 2018). Several studies report on the indirect effects of empowerment when in residential care, citing young people's experiences related to the (lack) of participation. Reported negative outcomes include the emotional and behavioural problems of children, such as oppositional behaviour as a consequence of being denied a voice; passiveness, as children stop asking or do not try to question or challenge a certain decision; and general bewilderment about how certain decisions relate to their own problems/situations (Ibid.). Madeleine Cocozza et al. (2006) point out that failing to include children's perspectives may decrease the chance of abuse and neglect being discovered and acted upon speedily, as it is more difficult for children who have no experience of participation to speak out about their experiences of abuse.

Participation of young people in decision-making procedures while staying in residential care may lead to better decisions and services; improve children's safety; make care arrangements more successful, and improve children's psychosocial well-being. However, evidence for the effects of successful or failed participation is insufficient (Vis et al. 2011; Ten Brummelaar et al. 2018). This lack of empirical evidence does not imply that participation does not work, but is testimony to the lack of rigorous research in the field.

The Family Code of Russia sets out the right of a child to express their opinion whenever a matter that affects their interests is considered in the family; the child also has the right to be heard at any court or administrative hearing (Federal Law 1995: Art. 57). Moreover, it is mandatory to take into account the opinion of children aged ten and above, except in situations when it would 
be against the child's best interests. The development of the fundamentals of children's empowerment, as well as fine-tuning and dissemination of relevant mechanisms and practices in Russia, has been going on for the last ten years. One of the six sections of the National Strategy of Actions in the Interests of Children for 2012-2017 (Decree of the President of the Russian Federation 2012) is dedicated to the involvement of children in making decisions that affect their interests. That section, however, has been the least successful in terms of implementation (Rubtsov et al. 2016). Researchers attribute the failure to the absence of relevant public monitoring indicators, which gives implementation the appearance of being 'optional' (Kalabikhina, Kuchmayeva 2016).

Russia remains a country with one of the highest proportions of children out of parental care and has a relatively high level of institutionalisation among such children (Biryukova, Sinyavskaya 2017). According to researchers, staff and administrators at such institutions often take decisions regarding the rights and duties of children in their care at their own discretion, without taking into consideration the children's views (Kalabikhina et al. 2014). We have failed to identify a single Russian empirical study that would describe the existing extent of involvement of children separated from parents in decision-making, especially in relation to the influence of such involvement on their psychosocial wellbeing. One potential reason why researchers avoid a focus on the child's role in decisionmaking is the predominance of the socialization perspective in childhood studies in Russia, while the sociology of childhood has not yet been broadly accepted and followed (Filipova 2016). In practical terms, the evolution of the child participation concept is impeded by a number of myths and stereotypes, such as the notion that children's empowerment is damaging to the parental authority and contradicts 'traditional family values' (Kalabikhina et al. 2014). Thus, in Russia the involvement of children in decision-making at the point of their separation from parents is often overlooked by both statistic monitoring and academic studies.

The present article seeks to fill in the above gaps and answer the following set of questions: To what extent is the right of children separated from their parents to participate in decision-making respected in Russia (based on this study of St.Petersburg)? How does involvement in decision-making impact their psychosocial wellbeing? We will answer these questions by considering first-hand opinions of children in the child protection system, i.e. by involving them.

\section{Studying children's participation in decision-making: The case of institutional care in St.Petersburg}

\section{Sample}

The study covered 215 children aged between ten and seventeen (mean age 13.8 2 2.2), living in nine care institutions in St. Petersburg. These institutions were formerly known as children's homes; since 2013 they have been 
renamed as 'Centres for the Promotion of Family Upbringing'. The sample comprised 114 boys and 111 girls; $93 \%$ of the respondents identify as ethnic Russians (russkii). In the sample, $56 \%$ of children found themselves in a children's home for the first time before the age of $10 ; 37 \%$ of children - at the age of ten to seventeen, and $7 \%$ of respondents said they either did not know or did not remember how they had come to be in the children's home.

The data in this survey were collected by means of a structured questionnaire. The questions were formulated in a simple concrete form, without the use of abstract and generalizing concepts, in a language understandable to children. A preliminary version of the questionnaire underwent a pilot study involving fifteen children. The survey and access to children's homes was approved by the governing authorities (The Committee of Social Protection). Researchers made a presentation of the study aim and methodology to fourteen directors of children's homes. The directors of five institutions refused to participate. According to Russian law, the director of the children's home is the official guardian of all children in the institution. In each of the remaining nine, we received written informed consent from director for the participation of all children in the survey.

All the children living in each institution who were on the premises on the day of the survey and conformed to the age limits were invited to take part in the survey. On the day of the study, according to the administrators of the children's homes, some children were away in connection with sporting or learning competitions or treatment. There is a possibility that some children could have been intentionally excluded from participation in the study - the researchers did not have the opportunity to verify this due to the anonymous nature of the survey. Based on the official data on the number of children aged ten to seventeen in the children's homes included in the research, the coverage of the children comprised $88 \%$.

The survey was carried out in two formats - self-completion of questionnaires in small groups (up to 10 children) and face-to-face interviews; the latter format was used if a child had vision, reading or attention span difficulties. The researchers appealed to the children as experts, stressed the significance of their answers, told that the survey results would be transferred to the governing authorities, and offered to get acquainted with the questions before making a decision about participating in the study. All children were informed that they have the right to refuse to participate in the survey immediately or at any time during the study without any negative consequences. Six children chose not to participate. Researchers made sure that adult carers did not interfere into the process of filling out the questionnaires, and collected the children's oral and written feedback on the questionnaire. Filling out the questionnaire took twenty to forty minutes. When discussing the questionnaire after filling it in, the children reported that they considered the questions important and reflected their lives in the children's home, and approved of the report being distributed to the governing 
bodies. The methodology and procedure of this study were described in more detail in our earlier publications (Odinokova et al. 2017).

\section{Measures}

Children's participation implies that the child's opinion is presented on all matters relevant to them, on the one hand, and that consideration is given to their opinion when making decisions affecting their interests, on the other. This study did not attempt to see if children's perceptions had been taken into account in decision-making at certain points in their lives, as this was outside the methodological scope of the study. We sought to study children's subjective point of view with regard to their participation in decision-making. Children's participation in decision-making was assessed on the basis of the following question: 'Do adults pay attention to your point of view when making decisions that are important for you (such as where and with whom you are going to live, where you are going to study, and on other important matters)?' A five-point scale was used to map the answers: always; almost always; sometimes; seldom; never.

Adolescent psychosocial wellbeing was measured using the Russian selfreporting version of the Strengths and Difficulties Questionnaire, SDQ (Goodman et al. 2005). The SDQ involves twenty-five items describing the positive and negative attributes of adolescents. The SDQ consists of five subscales of five items each: emotional symptoms, behavioural problems, hyperactivity/attention, peer problems, and prosocial behaviour. Scores for the first four subscales add up to a total difficulties score (TDS). We selected SDQ as the measure for children's psychosocial wellbeing in the residential care setting because it is one of the most widely used measures of children's mental health, and is sensitive to the treatment effects of specialist services for children (SDQ Website 2019).

In our further analysis, we also used the following measurements that describe the history and present conditions of living in children's homes: we asked the respondents about the age when they had first come to live in the children's home and the number of years spent in children's institutions in total. Contacts with the relatives were assessed via the question: 'With whom of your family do you keep in touch?', prompted by a list of relatives. The quality of relationships with the staff of the children's home was assessed via the question: 'Is there an adult in this children's home whom you can trust?' (Yes or No). Communication with the adults with regard to the child's rights was assessed via the question: 'Have you ever discussed your rights with adults? Please specify all those with whom you discussed your rights (family member, child care professional [vospitatel'], social counsellor [sotsial'nyy pedagog], director, representative of the guardianship authorities [organy opeki], etc.)?'

To understand the children's perception of whether their rights were violated in the children's home, we asked them the following question: 'In your opinion, have your rights been violated in the children's home?' (No, they have not; I am not sure; Yes, they have). The experience of abuse in the children's 
home was studied via the question: 'In the last 12 months, did anything of the following happen to you?' with the list of situations: 'somebody yelled at you, humiliated you, called you names, spread rumours, made you feel ashamed, or ridiculed...', 'somebody kicked, hit or beat you, twisted your ear, or did anything of the same kind...', 'any other cruel or sad things, i.e. something was stolen, taken from you by force, or damaged; you were ignored, excluded from group games or activities; you were photographed or video recorded against your will; offensive posts and comments were published in the Internet.' The respondents would mark down the cases and their frequency.

In order to assess the extent of isolation of the children from the external environment, we asked them the questions: 'How often do you get outside the children's home, and its grounds? (except for going to school)' and offered a 5-point scale for their answers: At least once a week; 2-3 times a month; Once a month; Several times a year; Once a year.

\section{Analysis}

The findings were analysed in two stages. In the first stage we considered the extent to which the right of children separated from their family to be involved in decision making is respected; and how this extent correlates with the social and demographic group the child belongs to, the age of arriving at the children's home, and the existence of communication with adults with regard to the child's rights.

In stage two, we verified the hypothesis that a child's participation is an important factor of their current psychosocial wellbeing. We performed a binary logistic regression analysis to assess whether participation in decisionmaking had driven children's psychosocial difficulties, measured by SDQ, leading to odds ratios (ORs) and 95\% confidence intervals (95\%-CIs). In our analysis, we adjusted for variables that might confound the association between our dependent and independent variables: age, gender, age of the first exposure to the children's home, existence of a 'trusted' adult in the children's home, keeping in touch with family members, experience of abuse in the children's home, lack of inclusion into the life outside the children's home. A p-value below 0.05 was considered statistically significant.

The quantitative and correlation-based nature of the study comes with certain limitations. In particular, we do not establish the contexts in which the child's view was heard, and the cause-and-effect relationship between (mis-) participation and psychosocial wellbeing.

\section{Results}

The distribution of answers to the question as to whether adults take account of the opinions of the respondents when making decisions that are important for the child is as follows: $28 \%$ 'always'; $27 \%$ 'almost always'; $23 \%$ 'sometimes'; 
$10 \%$ 'seldom'; $9 \%$ 'never'; and 3\% children did not answer the question. For further analysis, we dichotomized the values by the median and identified a group of children whose opinions were not sufficiently taken into account (answers: 'sometimes', 'seldom', and 'never'), which constitutes $42 \%$ of the sample. Our analysis (Table 1) shows that older children, those who have a trusted adult in the children's home, and those who regularly go outside the children's home are more likely to have been heard in decision making processes. Children reporting that adults 'always' or 'almost always' take their views into account are more likely to think that their rights in the children's home were never violated as opposed to those children who get heard 'sometimes', 'seldom', or 'never'. Gender, ethnicity and maintaining family ties did not relate with the chance to be heard; neither did the age when the child first found him/herself in the children's home (below ten, or ten and older). This latter finding was somewhat unexpected, as in Russian law the termination of parental rights is decided by court, and the child has the right to be heard by the court if he or she has already turned ten.

Table 1.

Distribution of various characteristics of respondents in their answers to the question 'Do adults take into account your point of view when making decisions that are important for you?' and Chi-square analysis of these differences

\begin{tabular}{|c|c|c|c|c|c|}
\hline $\begin{array}{l}\text { Characteristics } \\
\text { of respondents }\end{array}$ & 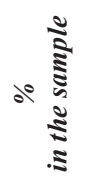 & 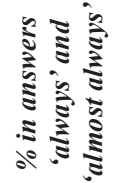 & 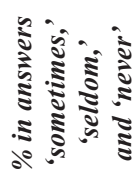 & 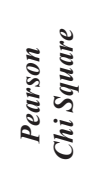 & 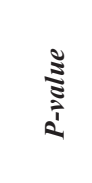 \\
\hline Gender (male) & 48.3 & 50.0 & 46.2 & 0.676 & not sig \\
\hline Age $(14+)$ & 56.4 & 62.6 & 48.3 & 0.047 & 0.029 \\
\hline Nationality (Russian) & 93.3 & 92.4 & 94.5 & 0.541 & not sig \\
\hline $\begin{array}{l}\text { Got into the children's } \\
\text { home for the first time } \\
\text { at the age of } 10+\end{array}$ & 37.3 & 38.1 & 36.3 & 0.781 & not sig \\
\hline $\begin{array}{l}\text { Keeps contact with } \\
\text { at least one natural } \\
\text { relative }\end{array}$ & 95.4 & 96.4 & 94.1 & 0.507 & not sig \\
\hline $\begin{array}{l}\text { Has a trusted adult } \\
\text { in the children's home }\end{array}$ & 79.8 & 89.4 & 67.8 & 14.506 & 0.000 \\
\hline $\begin{array}{l}\text { Goes outside } \\
\text { the children's home } \\
\text { at least once a week }\end{array}$ & 83.5 & 90.6 & 74.2 & 9.915 & 0.002 \\
\hline $\begin{array}{l}\text { Believes that his/her } \\
\text { rights were never violated } \\
\text { in the children's home }\end{array}$ & 49.3 & 61.0 & 34.1 & 15.035 & 0.001 \\
\hline
\end{tabular}


International studies show that involvement in decision-making largely depends on the motivations and attitudes of the specialists dealing with the case (Van Bijleveld et al. 2015; Cossar et al. 2016). Respondents in our study (Table 2) most often discussed their rights with their carers $(76 \%)$; every second child discussed their rights with the social counsellor $(45 \%)$; every third child with family members (33\%), or the director of the children's home (29\%) and with representatives of the guardianship authority $(28 \%)$.

Table 2 .

Distribution of positions of trusted adults of respondents in their answers to the question 'Do adults take into account your point of view when making decisions that are important for you?' and Chi-square analysis of these differences

\begin{tabular}{|c|c|c|c|c|c|}
\hline $\begin{array}{l}\text { Adult discussing } \\
\text { the child's rights } \\
\text { with the respondent }\end{array}$ & 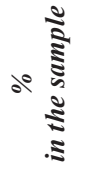 & 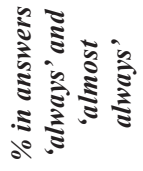 & 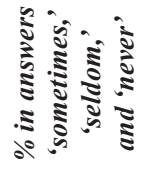 & 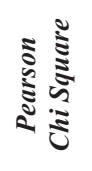 & 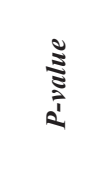 \\
\hline Child carer & 75.6 & 76.5 & 73.8 & 0.738 & not sig. \\
\hline Social counsellor & 44.7 & 53.1 & 28.6 & 6.724 & 0.008 \\
\hline Family members & 32.5 & 32.1 & 33.3 & 0.019 & not sig. \\
\hline Director & 29.3 & 32.1 & 23.8 & 0.918 & not sig. \\
\hline $\begin{array}{l}\text { Representatives of the } \\
\text { guardianship authority }\end{array}$ & 27.6 & 27.2 & 28.6 & 0.280 & not sig. \\
\hline Lawyer & 17.9 & 23.5 & 7.1 & 5.012 & 0.019 \\
\hline None & 12.2 & 11.1 & 14.3 & 0.260 & not sig. \\
\hline
\end{tabular}

The possibility of being heard had a statistically significant relation with discussions regarding the rights of children held with the social counsellor and lawyer. Social counsellors in children's homes are responsible for protecting the children's rights; they are in contact with family members and prospective adoptive families, they plan professional education programmes together with the child leaving the institution and perform other duties requiring the child's participation. Representatives of the guardianship authority are also responsible for protecting the children's rights; their duties involve inspecting the conditions of children's lives, and ensuring that their rights and legal interests are respected by guardians (i.e. directors of children's homes) in line with the Federal Law On Guardianship and Custodianship (2008). However, communication between children and these specialists does not increase the possibility of children being heard.

SDQ shows that every fifth child in our sample (22.5\%) has psychosocial difficulties (borderline or abnormal TDS). Involvement in decision-making shows a statistically significant relationship with the psychosocial difficulties 
(Person Chi Square $=18.462 ; \mathrm{p} \leq 0.000)$. Of those children who said their views were taken into account 'sometimes', 'seldom', or 'never', borderline or abnormal TDS is registered in $38 \%$ of cases; while among those children whose opinions were taken into consideration 'always' or 'almost always' - just in 12\% of cases.

Binary logistic regression shows a statistically significant relationship between psychosocial issues and limited participation in decisions, even if other factors are included into the model, such as the experience of abuse, contacts with family members, amount of years spent in the children's home, existence of a trusted adult and the frequency of going outside the children's home (Table 3). Limited participation made the odds of borderline or abnormal TDS with the child 2.5 times higher. The other independent variable with significant input into the model is the abuse suffered in the children's home in the last twelve months, which made the odds of borderline or abnormal TDS with the child 4.6 times higher. Thus, the experience of violence and the limited ability to be heard by adults together add to symptoms of mental health disorders among children in children's homes.

Table 3 .

Regression analyses to assess associations between participation in decisionmaking and psychosocial well-being (TDS) among children in residential care in St. Petersburg, Russia

\begin{tabular}{|c|c|c|}
\hline Variables & AOR (95.0\% C.I.) & P-value \\
\hline $\begin{array}{l}\text { Abuse suffered in the children's home } \\
\text { in the last } 12 \text { months (yes) }\end{array}$ & $4.617(1.207-17.662)$ & 0.025 \\
\hline $\begin{array}{l}\text { Adults listen to the child when making important } \\
\text { decisions (sometimes, seldom, never) }\end{array}$ & $2.458(1.001-6.039)$ & 0.050 \\
\hline $\begin{array}{l}\text { Goes outside the children's home } \\
\text { at least once a week (no) }\end{array}$ & $1.913(0.664-5.509)$ & 0.230 \\
\hline $\begin{array}{l}\text { Stayed at the children's home for } 5 \text { years } \\
\text { or longer (yes) }\end{array}$ & $1.015(0.527-1.954)$ & 0.964 \\
\hline $\begin{array}{l}\text { Keeps contact with at least one natural } \\
\text { family member (yes) }\end{array}$ & $0.711(0.110-4.598)$ & 0.720 \\
\hline Gender (male) & $0.499(0.203-1.225)$ & 0.129 \\
\hline $\begin{array}{l}\text { Existence of a trusted adult } \\
\text { in the children's home (no) }\end{array}$ & $0.868(0.310-2.429)$ & 0.788 \\
\hline Age $(14+)$ & $0.543(0.217-1.357)$ & 0.191 \\
\hline Constant & 0.056 & 0.057 \\
\hline
\end{tabular}

Nagelkerke R Square $=0,231$ 


\section{Conclusion}

The study suggests that two of five children aged ten and above living in children's homes believe that their views were not heard when making decisions affecting the child's interests. More often the child's perspective is taken into account with senior teenagers and in the context of communication with the social counsellors and lawyers. Supposedly, the child's opinion is more or less systematically taken into account in the context of choosing the trajectory of professional or vocational education at the time of completion of school education (9th grade, about 16 years old). Involvement of lawyers is specific for the period of preparing the child to leave the children's home (18-23 years old) as it is associated with the implementation of housing law and the determination of the next place of residence.

Our study shows that limited participation in decision-making increases the odds of psychosocial difficulties among children living in institutional care. This association can have two concurring explanations. On the one hand, the adults may tend to make decisions for children with unstable emotional status and behavioural issues, and discuss life plans with those children, who are easier to communicate with, because of their better mental health. On the other hand, the chance to be heard may be an independent factor of the child's mental health, as suggested by other studies. For example, Svein Arild Vis et al. (2011) argue that children who have limited opportunity to participate in decision-making feel that they are not in control and are disoriented. Contrary to this, children involved in decision-making processes can better cope with stresses of changing life conditions. Further research based on a longitudinal methodology is needed to confirm the long-term effects of participation in decision-making on the mental health and social well-being of children within institutional care and after leaving the institutions - whether living with a family or independently.

We have found that - along with the participation in decision-makinga crucial factor of psychosocial difficulties is experience of abuse in the children's home. Limiting the child's chances to be heard also limits the chance of abuse becoming known to adult professionals, and reduces the opportunities for a child with no decision-making experience to report wrongdoing to adults. Our data proves the importance of paying attention to the child's perspective in the context of the child protection system for better children's safety within the walls of the institution and better mental health.

The extent and effectiveness of children's participation largely depends on the professional paradigm of people involved in the case (Van Bijleveld et al. 2015; Cossar et al. 2016). In our study, we found that talking with a social counsellor, but not with a representative of guardianship authorities, adds to children's perceptions that they have been heard. This raises questions about the knowledge, attitudes, and professional competence of the representatives 
of the guardianship authorities, who are the main stakeholders in the child protection field in Russia. To some extent, this result is explained by the fact that the professional standard of the specialist of the guardianship bodies was introduced relatively recently, in 2015. In addition, the existence of a trusted adult in the children's home is associated with the children's perception of being heard when important decisions are made.

Multiple barriers exist in the way of creating opportunities for children's participation, such as professionals' lack of understanding of what participation actually means, their perception of the young person as immature, and the urgent impulse to protect the child by not letting him or her participate in 'difficult' decisions. Our results indicate the need to increase knowledge and improve attitudes among professionals in relation to children's participation. Children's participation should not remain a matter of legal and academic discourse, but must be introduced in everyday practices.

The study demonstrated that children have an intense need to communicate their opinions to decision-makers. The survey gave them such an opportunity, which they used with a responsible attitude. Children's participation in decision-making can increase the effectiveness of interventions by better adjusting them to the child's needs and allowing for more issues to be addressed and more realistic plans to be made.

\section{Acknowledgements}

The study was funded by the Russian Science Foundation (№ 16-18-10372).

\section{References}

Biryukova S., Sinyavskaya O. (2017) Deti bez popecheniya roditeley v Rossii: chto my mozhem uznat' iz statistiki [Children without Parental Care in Russia: What Can We Learn from Statistics]. The Journal of Social Policy Studies, 15 (3):367-382.

Cocozza M., Gustafsson P.A., Sydsjo G. (2006) Child Protection in Sweden: Are Routine Assessments Reliable? Acta Paediatrica, (95): 1474-1480.

Corsaro W.A. (1997) The Sociology of Childhood. Thousand Oaks, CA: Sage.

Cossar J., Brandon M., Jordan P. (2016)'You've Got to Trust Her and She's Got to Trust You': Children's Views on Participation in the Child Protection System. Child \& Family Social Work, 21 (1): 103-112.

Decree of the President of the Russian Federation (2012) On the National Strategy of Actions for Children for 2012-2017 N 761 from 1 June 2012.

Federal Law (1995) Family Code of the Russian Federation N 223-FZ from 29 December 1995.

Federal Law (2008) On Guardianship and Custodianship N 48-FZ from 24 April 2008. 
Goodman R., Slobodskaya H., Knyazev G. (2005) Strengths and Difficulties Questionnaire. Available at: http://www.sdqinfo.com (accessed: 7 April 2019).

Filipova A. G. (2016). Detstvo v fokuse otechestvennykh sotsiologicheskikh issledovaniy [Childhood is the Focus Of Domestic Sociological Research]. Vestnik Nizhegorodskogo universiteta im. NI Lobachevskogo. Seriya: Sotsial'nyye nauki [Bulletin of the Nizhny Novgorod University NI Lobachevsky. Series: Social Sciences], 1 (41): 80-87.

James A. (2009) Agency. In: J. Qvortrup, W. A. Corsaro, M.-S. Honig (eds.) The Palgrave Handbook of Childhood Studies. Hampshire: Palgrave Macmillan:34-45.

James A., Prout A. (eds.) (1997) Constructing and Reconstructing Childhood: Contemporary Issues in the Sociological Study of Childhood. London: Falmer.

Kalabikhina I., Kuchmaeva O. (2016) Problemy i perspektivy monitoringa uchastiya detey v realizatsii 'Natsional'noy strategii deystviy v interesakh detey na 2012-2017 gg.' [Challenges and Prospects for Monitoring the Participation of Children in the Implementation of the 'National Action Strategy for Children for 2012-2017']. The Journal of Social Policy Studies, 14 (4): 507-520.

Kalabikhina I.E., Kuchmaeva O.V., Lukovitskaya E.G. (eds.) (2014) Metodicheskiye rekomendatsii po razvitiyu uchastiya detey $v$ prinyatii resheniy, zatragivayushchikh ikh interesy, $v$ munitsipal'nykh obrazovaniyakh [Methodological Guidelines or the Development of Children's Participation in Decision-Making Affecting Their Interests in Municipalities]. Moscow: Fund to support children in difficult situations. Available at: http://www.fond-detyam. ru/pechatnye-izdaniya/11502/ (accessed 26 April 2019).

Odinokova V.A., Rusakova M.M., Usacheva N.M. (2017) Opyt otsenki blagopoluchiya detey $\mathrm{v}$ uch rezhdeniyakh dlya deteysirot [Experience of Evaluation of Well-being of Children Living in State Care Institutions for Orphans]. Monitoring obshchestvennogo mneniya: Ekonomicheskiye i so tsial'nyye peremeny [Monitoring of Public Opinion: Economic and Social Changes], (2): 129-144.

Rubtsov V. V., Shvedovskaya A. A., Dubovik A. S., Semya G. V. (2016) Ob osnovnykh rezul'tatakh monitoringa pervogo etapa realizatsii Natsional'noy strategii deystviy v interesakh detey na 2012-2017 gody [Monitoring the First Phase of the Implementation of the Strategy on Action for Children 2012-2017: Main Outcomes]. Psikhologicheskaya nauka i obrazovanie [Psychological Science and Education], 21 (1):30-66.

SDQ Website (2019) Homepage. Available at: http://www.sdqinfo.com (accessed 7 April 2019).

Ten Brummelaar M. D., Harder A. T., Kalverboer M. E., Post W. J., Knorth E. J. (2018) Participation of Youth in Decision-Making Procedures during Residential Care: A Narrative Review. Child \& Family Social Work, 23 (1):33-44.

UN (1989). Convention on the Rights of the Child. Available at: http://www.ohchr.org/EN/ ProfessionalInterest/Pages/CRC.aspx (accessed 26 April 2019).

United Nations Committee on the Rights of the Child (2009) The Right of the Child to be Heard. CRC/C/GC/12. General Comment No. 12.

Van Bijleveld G. G., Dedding C. W., Bunders-Aelen J. F. (2015) Children's and Young People's Participation within Child Welfare and Child Protection Services: A State-of-the-art Review. Child \& Family Social Work, 20 (2): 129-138. 
Vis S. A., Strandbu A., Holtan A., Thomas N. (2011) Participation and Health-A Research Review of Child Participation in Planning and Decision-Making. Child \& Family Social Work, 16 (3): 325-335.

Qvortrup J. Bardy M., Sgritta G., Wintersberger H. (eds.) (1994) Childhood Matters: Social Theory, Practice and Politics. Public Policy and Social Welfare. Aldershot, UK: Avebury. 